\title{
IMPLEMENTATION OF GRAMMAR-TRANSLATION METHOD OF TEACHING FOREIGN LANGUAGES IN ENGLISH TEXTBOOKS OF BUKOVYNA (1872-1900)
}

\author{
Bohdana Labinska \\ Chernivtsi National University, Chernivtsi, Ukraine \\ b.labinska@chnu.edu.ua \\ Oksana Tumak \\ Chernivtsi National University, Chernivtsi, Ukraine \\ oksanatumak@gmail.com
}

\begin{abstract}
The article describes the features of teaching English in Bukovyna (a region in western Ukraine, which was a part of former AustroHungarian Empire) in the late 19 century and the manifestation of the European leading pedagogical ideas in English textbooks of the period. The emergence of the English language teaching methodology in Bukovyna is reflected in the school curricula of the region. The functions of foreign language textbooks are presented, which include: communicative; informational; organisational and managerial; developing and educating. English textbooks have been analysed according to these functions and criteria developed in modern methodology. The two main groups of English textbooks were differentiated: grammar references and readers. It was found that the structure and content of English textbooks corresponded to the curriculum approved by the Austro-Hungarian Ministry of Culture and Education. A lot of attention was paid to grammar material which was presented in German (the official language of the Empire) in the form of rules and commentaries; the exercises were mainly translational, reproductive and non-communicative. The reader included literary excerpts of different genres without providing pre-reading or post-reading tasks. The textbooks analysis proved the use of the approaches and principles of the grammar-translation method of teaching foreign languages which implied predominance of learning grammar, writing and translation over speaking.
\end{abstract}

Keywords: Bukovyna; English textbook; grammar-translation method; content; structure.

\section{Introduction}

The development of science is impossible without knowing the root causes of its origin, examination of its formation stages, the analysis and creative rethinking of the past experience, critical evaluation of its achievements. English teaching methodology is in a state of constant change and transformation. At present, particular emphasis is laid on the study of the historical nature of the methodology, when the restoration of the historical truth is taking place. The discovery and disclosure of previously unknown documents open up new scientific horizons in the methodological sphere, which makes it possible to outline new educational goals and tasks. The study of regional history becomes relevant in the light of current events taking place in the public life of Ukraine. In the process of implementing the new English teaching strategies, attention is focused on the historical and pedagogical experience gained during various periods.

Having been a Ukrainian region which belonged to different countries during its history, Bukovyna has become multinational and multilingual, with a variety of religions and cultures. Its Austrian-Hungarian period is marked with positive changes in its social life, particularly with the emergence of English teaching methodology in the region. A retrospective study of this phenomenon is significant as it reflected the main ideas of English teaching methods, which were prevailing in Europe in the second half of the 20th century.

The development of education in Bukovyna was revealed in the following works. Penishkevych (2002) analysed the development of Ukrainian schooling in Bukovyna in the 18th - early 20th centuries; Kobylianska (1998) characterised the formation and development of Ukrainian folk schools in Bukovyna (in the 1970s and early 20th centuries); Petriuk (1999) investigated the formation and development of general secondary education in Bukovyna (the end of the 18th - the beginning of the 20th century); Labinska (2013) analysed the tendencies of the foreign language teaching methods in the Western Ukraine (the second half of the 19th - the first half of the 20th centuries); Botushanskyi (2017) described events, phenomena, facts and processes which influenced the development of primary and secondary schools in Bukovyna, classical and specialised training and higher education in the region in the 19th - early 20th centuries.

The historiographical search showed that trends in the development of English teaching methodology in Bukovyna as a separate scientific problem were not investigated. Thus, the aim of the paper is to analyse the structure and content of English textbooks in Bukovyna in 1872 - 1900 and specify the ways of the grammar-translation method implementation.

Labinska, B. \& Tumak, O. (2019). Implementation of grammar-translation method of teaching foreign languages in English textbooks of Bukovyna (1872-1900). Advanced Education, 12, 44-48. DOI: 10.20535/2410-8286.124677 


\section{Methods}

Analysis, synthesis, induction, deduction, abstraction, comparison and synthesis were used for the study of literary sources. The critical analysis of educational documents, curricula and textbooks in English and German has been made. Hermeneutic method was used to preserve the authentic verbatim content of the translation and interpretation of the textbooks and school curricula.

\section{The problem of textbooks evaluation}

Roman and Kolominova (2006) note that a successful textbook allows teacher to better concentrate on the quality of the planned lesson, without wasting time searching for or creating the necessary teaching materials and explanations. And for the student, such a textbook is a tool of rational activity, driven by a teacher, an instrument that helps him build his communication with a teacher, perform his independent work consciously, economically, creatively, purposefully and efficiently (p. 51). The textbook is also considered as a means by which the main features of the modern methodological system of teaching foreign languages (TFL) are modelled, and in accordance with this system, a specific learning process is implemented. Redko (2005) emphasises that the textbook is a model of the education system, it directs the activities of teachers and students in compliance with the concept of learning that it implements (pp. 50-55).

The issue of evaluating the content of the textbooks is closely related to the criteria for their analysis and evaluation, which enable to objectively assess, analyse, and summarise the accumulated experience due to transformational processes. We share the opinion of Borysko (1999), according to which, a textbook is a subsystem within the TFL system which reflects and simulates all its elements. Therefore, all the elements of the TFL system are the objects of analysis and evaluation (p. 22). The textbook tasks follow from its main functions, namely: communicative; informational; organisational and managerial; developing and educating. The following criteria developed by Borysko (1999) were used in our analysis of English textbooks: social needs of a society; specific educational and methodological conditions; psychological and methodical concept of textbooks; learning objectives; the content of the educational process; structure and volume; macrostructure; microstructure; technical presentation of individual components (p. 25).

\section{The analysis of the English textbooks used in Bukovyna schools of the period under investigation}

We selected only those English textbooks, which were recommended by the Ministry of Education and Religion of Austria-Hungary. We found the textbooks of this period and divided them into two groups: grammar references, which contained the rules of English grammar and training exercises, and books for reading, "readers", which included various texts for reading at home.

"Lehrbuch der englischen Sprache (The English Textbook)", composed by Dr. Hermann Gesenius in 1881, was recommended by the Ministry for teaching English in real schools (secondary schools in AustriaHungary). In the foreword, the author notes that this is the second, improved edition, made in the light of the comments and wishes of the teachers, who used this book in their practice. Gesenius (1881) admits that the order of the grammar material presentation was a difficult problem for him. Therefore, the textbook compiler tried to adhere to the principle "from the simple to the complex" (Gesenius, 1881, p. I). The author claims that he avoided the use of uncommon words in order not to overload the students' memory with unnecessary information, as well as to reduce the rules as much as possible to facilitate their perception and understanding (p. III).

So, the textbook consists of four parts: the First Course (Morphology and the most important syntax rules), the Second Course (Syntax combined with the extension of morphology), sentences and excerpts of texts for translation, vocabulary to the exercises and an alphabetical index of the proper names appearing in exercises. We should note that the textbook is written in German, which was the official language of AustriaHungary. It was used for writing grammatical rules and other commentaries. In addition, all examples, which were provided in English, were also translated into German.

At the beginning of the First Course, we can see a brief phonetic reference, reading rules, some examples. Morphology included such topics as articles, case of nouns, verbs "to have", "to be" (in all their forms), possessives and plural nouns, forms of verbs in the active and passive voice, word order, pronouns, questions, auxiliary verbs, numerals, adverbs, irregular verbs, modal verbs, prepositions, and conjunctions.

The Second Course also begins with the articles, where the rules are much more voluminous, expanded, more examples are given and some exceptions are added. The same applies to other grammatical topics that are described in more detail than in the First Course. In addition, there are such topics as "Gerund" and "Participles", as well as "Punctuation". At the end of the course, we can see a table of phrasal verbs and adjectives that are used with certain prepositions and the table of irregular verbs. 
The Third Course is represented by exercises for the revision of the grammar rules. It is noteworthy, that all exercises are receptive-reproductive and non-communicative, in which students work with linguistic material, taken out of the context, focusing only on the grammar forms. In this textbook, we can see practical tasks which include translating unrelated sentences from German into English. We suppose that these exercises were not helpful for the students' acquisition of grammar material. Besides, they did not contribute to the formation of communication skills. Being monotonous and complex, the translation exercises did not form a positive attitude towards the study of English and aroused low motivation in students.

At the same time, in our opinion, the textbook by Gesenius (1881) was a step forward and a sign of the progressive tendencies that took place in Bukovyna education during this period. It performed the main functions, assigned to a foreign language textbook of that time: modelling the elements of learning and their interconnections, served as the main means of learning, meeting the needs of the curriculum. This textbook structured and organised the process of learning English due to its division into sections and topics, giving teachers the opportunity to plan and carry out the educational process.

Another English textbook was designed by Gaspey "Englische Konversations-Grammatik zum Schul und Privatunterricht (English Conversation Grammar for School and Private Classes)" published in 1883. In the preface, the author notes that there were 18 reprints of this textbook. Gaspey (1883) explains the success of his textbook by the use of an effective method of teaching English. The method lies in the sequence, in which the material was presented, providing exercises for the lectures, as well as examples, reading excerpts which ensured the progress in teaching English (p. I).

"Englische Konversations-Grammatik" (1883) consisted of two parts which contained theoretical grammar material. As well as the textbook mentioned before, this one started with essential phonetic rules. Beginning with p. 27, the students studied grammar rules in the form of short lectures, written in German. The author gave many examples so that the students could better understand the rules; also, we can see vocabulary notes with the translation of lexical units, which the students encountered in the practical tasks. After each lecture, there were exercises of different types: reading exercises, translation exercises and conversations. The exercises for reading were presented by a set of sentences which were not connected to each other textually. For example:

\section{I have the pen. 2. He has the table. 3. She has not the ink. 4. It has the spoon (Gaspey, 1883, p. 28).}

Translation exercises consisted of sentences in German. For example:

1.Ich habe den Tisch. 2. Er hat die Lampe. 3. Sie hat das Glas (Gaspey, 1883, p. 28).

Conversations had a form of dialogues:

$\begin{array}{ll}\text { Lehrer (teacher). } & \text { Schüler (pupil). } \\ \text { Have I the pen? } & \text { You have the pen. } \\ \text { Has he the ink? } & \text { Yes, he has the ink. } \\ \text { Has she the paper? } & \text { Yes, she has the paper (Gaspey, 1883, p. 29). }\end{array}$

The exercises became longer and more complicated with each lecture.

The First part ended with the tables of irregular verbs, irregular plural forms of the nouns of foreign origin, contractions written in the alphabetical order. Here we can see samples of letters and punctuation marks (Gaspey, 1883, p. 170 - 172).

The Second part also consisted of grammar rules and exercises, but here the theory was presented much more briefly and the exercises are more extensive. In this part, the exercises were connected textually, both for reading in English and translation from German into English.

The same vocabulary is practised in all exercises of the lesson which helped students learn the words more efficiently. At the end of the Second part, the author presented phrasal verbs and proverbs. We can assume that the second part was the revision of the first one. At the end of the textbook, there were more dialogues, tales, stories etc. to provide more practice to students. Also, we can read some essays on the history of England, a table of English monarchs, the chronology of the best-known English authors with the titles of their main works.

To sum it up, Gaspey's textbook (1883) reflected the main ideas of English teaching methods, which were prevailing in Europe in the second half of the 19th century. It had a logical structure, interesting arrangement of the learning material and combined elements of grammar references and readers. The author of this textbook tried to meet the needs of the society, making it convenient for both students and English teachers. It performed most of its basic functions and met the requirements of curricula in secondary schools of Bukovyna of that historical period. 
Another English textbook was Rothwell's "Vereinfachte, theoretisch-praktische Schulgrammatik der englischen Sprache (Simplified, theoretical-practical school grammar of the English language)" (1868). The textbook was intended for teaching English in gymnasia, female secondary schools and other educational institutions. The book consisted of three parts and appendices. Grammar rules were presented in the form of questions and answers. Some examples were given to illustrate the rules. The sentences were not related to each other by content. We can see comparisons of some English grammatical constructions with the Latin and French ones (Rothwell, 1868).

The first appendix contained lexical units on specific topics (universe, nature, humans, meals etc.). The second appendix included excerpts for reading, some general information and the history of the English language. The translation of new lexical units is given for each text in footnotes at the bottom of the page. The third appendix contains words and language clichés for writing letters; the fourth appendix included the list of proper names, many of which were exceptions from the rules.

In our opinion, the author offered his own English teaching method, which included both the basics of the translation method and some elements of the direct method of TFL. The main principles of the translation method included a predominance of written text over speaking; learning grammatical rules and lexical units, and then making up sentences on their basis; language acquisition through translation and learning by heart. In the textbook, special attention is paid to memorising grammatical rules, which the author mentions in the preface to the edition (Rothwell, 1868). Besides, the students were supposed to translate the reading pieces from English into German. Considering the approaches of the direct method, the author paid attention to the English pronunciation, provided vocabulary and dialogues to develop conversation skills. The examples of official and private correspondence were given to improve proficiency in writing.

The only reader found is "Englisches Lesebuch für die oberen Klassen höherer Lehr-Anstalten (The English reading book for the upper classes of higher education institutions)" by Seeliger, published in 1877. The book consisted of a foreword, a table of contents, texts and remarks at the end. In the foreword, Seeliger (1877) observed that since pupils first learned French as a foreign language, this was a good precondition for learning English (p. I). Beginning with a simple analysis, the student took important steps from letters to a free conversation, got to know how to work with a dictionary, the rules of the other language, a different outlook, learned to think in a foreign language. The author's idea was to add longer works of literature, which had logical development and completion. As to the notes at the end of the textbook, the author preferred the linguistic etymological and syntactic commentaries to help teachers (Seeliger, 1877, p. II).

The table of contents of the textbook was presented in German. The author translated the names of all literary works which were included in it. The material was divided into genres and had 7 parts: stories, history and biographies, descriptions, didactics, rhetoric, letters and dramatic works. The author did not provide a dictionary intentionally. Students were supposed to focus on trying to understand the underlying idea of the context rather than on the translation of all the words.

Taking the main functions of the textbooks as the basis of the analysis, we can say that "The English reading book" by Seeliger (1877) did not perform them to the fullest. In particular, it was aimed at the mastering of reading competence. At the same time, one of the main elements of the learning process - a means of control and evaluation - was lacking. We can see only literary works without pre-reading and postreading exercises. Thus, there was a purely receptive learning of the material. Besides, the textbook was a source of linguistic and extra-linguistic information. Materials followed one of the fundamental methodological principles - authenticity. In a way, the textbook by Seeliger (1877) gave students the motivation to learn English, so that they could freely read the works of English-speaking authors.

\section{Conclusions}

The textbooks, which were used for teaching English in Bukovyna in 1872-1900 fulfilled the majority of their functions. They contained authentic material, were thoroughly organised and structured. The main didactic and methodological principles were adhered to. These textbooks met the requirements of the curriculum and were approved by the Ministry of Education and Religion of Austria-Hungary.

The analysed textbooks fully corresponded to the type of educational institution in which English was studied. Methodological concepts of textbooks were presented by the authors in the preface and were implemented through the arrangement of the learning content. The textbooks contained samples of written speech, and the linguistic material was selected according to the purpose of learning (knowledge of grammar, reading and translation). Structurally, textbooks were divided into parts, each containing all main components (grammar material, exercises, texts, lexico-grammatical commentary). The textbooks ensured step-by-step learning of English. 
We assume that the four textbook compilers Gesenius (1881), Gaspey (1883), Rothwell (1868) and Seeliger (1877) were trying to stick to the principles of the grammar-translation method of TFL, which was popular in Europe at the end of the 19th century. They provided theoretical material in German. Grammar was presented deductively, i. e. first the rules were provided, and then the examples were given. A lot of attention was paid to the comparison of English with German and French and the students had to analyse grammar phenomena. The exercises were mostly translational and reading ones. So, the students were supposed to read and memorise the rules and translate sentences from German into English. In some books, we can observe the elements of communication. It means that the authors were trying to improve their methods and make their textbooks more practical and up-to-date to meet the needs of the society.

Such techniques of the translation methods as explaining grammar in students' mother tongue, making comparisons with their native language, using translation from a foreign language into native and vice versa, reading original texts, some kinds of work with the text are used today in the process of teaching English.

\section{References:}

Borysko, N. F. (1999). Kriterii analiza i otsenki uchebno-metodicheskikh kompleksov po inostrannym yazykam [The criteria of the analysis and evaluation of textbooks and teaching-methodological complexes in foreign languages]. Inozemni movy, 1, 22-25.

Botushanskyi, V. M. (2017). Narysy z istoriyi osvity na Bukovyni (XIX - pochatok XXI st.) [Essays on the history of education in Bukovina (XIX - early XXI cent.)]. Chernivtsi, Ukraine: Tehnodruk.

Gaspey, T. (1883). Englische Konversations-Grammatik zum Schul- und Privatunterricht [English Conversation Grammar for School and Private Classes]. Heidelberg.

Gesenius, H. (1881). Lehrbuch der englischen Sprache [The English Textbook]. Halle.

Kobylyanska, L. I. (1998). Stanovlennya i rozvytok ukrayinskykh narodnykh shkil na Bukovyni (70-ti rr. XVIII - pochatok XX st.) [Formation and development of the Ukrainian folk schools in Bukovina (70s of the XVIII - early XX century)].Unpublished PhD dissertation), Vasyl Stefanyk Precarpathian National University, Ivano-Frankivsk, Ukraine.

Labins'ka, B. I. (2013). Istorychni narysy z metodyky navchannya inozemnykh mov na zakhidnoukrayins'kykh zemlyakh (druha polovyna XIX - persha polovyna XX st.) [Historical sketches on the methodology of teaching foreign languages in the Western Ukrainian lands (the second half of the XIX - the first half of the XX century)]. Kyiv, Ukraine: KNLU.

Penishkevych, O. I. (2002). Rozvytok ukrayinskogo shkilnytstva na Bukovyni (XVIII - pochatok XX st.) [Development of the Ukrainian schooling in Bukovyna (XVIII - early XX century)]. Chernivtsi, Ukraine: Ruta.

Petriuk, I. M. (1998). Stanovlennya i rozvytok zahalnoyi serednioyi osvity na Bukovyni (kinec' XVIII - pochatok XX st.) [Formation and development of general secondary education in Bukovina (late XVIII - early twentieth century)]. Unpublished PhD dissertation), Vasyl Stefanyk Precarpathian National University, Ivano-Frankivsk, Ukraine.

Red'ko, V. (2005). Pidruchnyk yak model' systemy navchannya (Osoblyvosti navchannya inozemnoyi movy uchniv osnovnoyi shkoly kriz' pryzmu vitchyznyanoho pidruchnykotvorennya) [Textbook as a model of a learning system (Features of teaching foreign language to the students of the secondary school through the prism of domestic textbooks)]. Inozemni movy v navchal'nykh zakladakh, 2, 50-55.

Roman, S. V., Kolominova, O. O. (2006). Funktsiyi pidruchnyka angliys'koyi movy dlya pochatkovoyi shkoly [Functions of English textbooks for the primary school]. Inozemni movy, 1, 51-56.

Rothwell, J. S. S. (1868). Vereinfachte, theoretisch-praktische Schulgrammatik der Englischen Sprache [Simplified, theoreticalpractical school grammar of the English language]. München: Verlag von Jul. Grubert.

Seeliger, E. (1877). Englisches Lesebuch für die oberen Klassen höherer Lehr-Anstalten [The English reading book for the upper classes of higher education institutions]. Wien: Fischer. 